\title{
Hepatitis B virus-associated intrahepatic cholangiocarcinoma: a malignancy of distinctive characteristics between hepatocellular carcinoma and intrahepatic cholangiocarcinoma
}

\author{
Seogsong Jeong ${ }^{1, *}$, Ying Tong ${ }^{1, *}$, Meng Sha ${ }^{1}$, Jinyang $\mathbf{G u}^{1}$ and Qiang Xia ${ }^{1}$ \\ ${ }^{1}$ Department of Liver Surgery, Renji Hospital, School of Medicine, Shanghai Jiaotong University, Shanghai, China \\ * These authors have contributed equally to this work \\ Correspondence to: Jinyang Gu, email: gjynyd@126.com \\ Qiang Xia, email: xiaqiang@shsmu.edu.cn
}

Keywords: hepatitis B virus-associated intrahepatic cholangiocarcinoma; prognosis; treatments; cancer-associated lymphangiogenesis; mesenchymal-to-lymphatic endothelial transition

Received: October 29, $2016 \quad$ Accepted: December 13,2016 Published: December 21, 2016

\section{ABSTRACT}

It has been a decade since hepatitis B virus infection was identified as an etiological factor for the development of intrahepatic cholangiocarcinoma (ICC). In recent years, several studies have elucidated the critical impact of hepatitis $B$ virus in ICC that significantly influenced the clinicopathological characteristics of ICC patients with intrahepatic cholangiocarcinoma. Distinctive features of patients with hepatitis B virus-associated ICC included younger age, preponderance of male patients, frequent elevation of alpha-fetoprotein, and infrequent lymph node metastasis. Furthermore, several studies indicated that the presence of hepatitis $B$ virus is a favorable prognostic factor in terms of overall survival and relapse-free survival. However, there are also a few studies demonstrating that hepatitis $B$ virus negatively influenced or showed no significant association with survival outcomes of patients with ICC. At present, there are no consensus on diagnostic procedures and treatments for such population. Therefore, we elucidated current knowledge and recent identifications of HBV-associated ICC to clarify the impact of chronic HBV infection on patients with ICC and to precisely conduct diagnostic procedures and curative treatments for HBV-associated ICC.

Intrahepatic cholangiocarcinoma (ICC) is a poorly understood, aggressive malignancy with an increasing incidence, and etiological factors are just starting to be elucidated $[1,2]$. Previous publications on this malignancy are severely limited principally to clinical series from specialized hepatobiliary surgery. In recent years, several studies indicated that hepatitis B virus (HBV) infection, which is a common cause of both liver cirrhosis and hepatocelluar carcinoma (HCC), is also found to be a risk factor for ICC. HBV-associated ICC patients displayed significantly different clinicopathological characteristics as well as survival outcomes [3-5]. However, there are no diagnostic procedures and treatment prescription for this group of patients. In addition, many aspects of this relatively rare malignant disease are insufficiently understood, rendering the present literature hard to interpret. HBV-associated ICC lacks evaluation and its diagnosis and treatment have been the topic of few studies. In this review, we report current knowledge and recent discoveries on HBV-associated ICC so that clinicians need to be aware of establishing curative treatments efficiently.

\section{HBV INFECTION AND THE DEVELOPMENT OF ICC}

To date, several risk factors for ICC have been identified, such as primary sclerosing cholangitis (PSC), hepatolithiasis, Caroli's disease, parasite infestation, hepatitis virus infection, and the risk factors vary according to region $[6,7]$. Recently, hepatitis $\mathrm{B}$ virus 
has been associated with an increasing incidence of ICC in East Asian countries where it is endemic [8, 9]. A Japanese experience indicated that a seroprevalence of hepatitis B surface antigen (HBsAg) and hepatitis C virus (HCV) was found in $10 \%$ and $20 \%$ of patients with ICC, respectively [10]. In addition, Li et al. [11] used a diagnostic kit to detect the presence of serum HBV DNA in 104 of $183(56.83 \%)$ sporadic ICC patients, confirming that seropositivity for HBsAg is indeed found to be a risk factor for ICC. Another study confirmed the generation of HBx protein in $70.4 \%(38 / 54)$ of paraffin-embedded $\mathrm{HBV}$-associated ICC specimens, indicating that HBx may play a significant role in the development of ICC [12]. Furthermore, a meta-analysis demonstrated that all included studies revealed a statistically significant increased risk for ICC among ICC patients with HBV infection (rate ratio [RR], 2.66; 95\% confidence interval [CI], 1.97 to 3.60$)$, and the pooled risk estimate of Asian publications (RR, 3.63; 95\% CI, 2.56 to 5.13) was relatively higher than studies from other regions (RR, $1.93 ; 95 \%$ CI, 0.78 to 4.76 ) [13]. However, there are also a few publications which could not confirm a significant association between viral hepatitis and the incidence of ICC [14]. In summary, there is consistent epidemiological evidence supporting a correlation between HBV infection and ICC, especially where HBV is endemic. However, current information is not enough to elucidate a specific mechanism to support the link between HBV and ICC.

In previous relevant publications, the distribution of $\mathrm{HBV}$-associated ICC was found to vary worldwide with the lowest distribution found in US $(1 / 625,0.2 \% ; 1 / 83$, $1.2 \%)$ and the highest in China $(154 / 317,48.6 \% ; 31 / 98$, $31.6 \% ; 26 / 97,26.8 \%$ ) [25-28]. The other Asian countries such as Korea $(4 / 51,7.8 \% ; 84 / 622,13.5 \%$; 37/292, $12.7 \%)$ and Japan $(2 / 50,4 \% ; 3 / 41,7.3 \%)$ were found to have a moderate distribution of HBV-associated ICC [5, 8, 29-31].

\section{CLASSIFICATION}

A consensus on the classification of ICC has yet to be reached due to inconsistencies in definition. In 2003, Yamasaki et al. [33] demonstrated that ICC can be stratified into three different subtypes: intraductal, periductal infiltrating, and mass-forming according to its morphological features. Previous studies revealed that intraductal and periductal types develop from the malignant transformation of epithelial cells of relatively large bile ducts, whereas mass-forming type originates from bi-potential hepatic stem cells inner portal areas or relatively small bile ducts [34]. A few etiological factors of ICC, such as hepatolithiasis and Clonorchis sinensis infection, were found to be associated with the intraductal type [35-37]. In contrast, most ICC patients with $\mathrm{HBV}$ infection were found to have the mass-forming type $[38,39]$. On the basis of the histological features,
ICC could also be further stratified into two different types: cholangiolar type and bile duct type. According to a previous publication, Yu et al. [40] suggested that the presence of viral hepatitis infection, including HBV and $\mathrm{HCV}$, was found to be associated with the cholangiolar type of $\mathrm{ICC}(\mathrm{OR}=2.71 ; \mathrm{P}=0.008)$.

\section{CLINICOPATHOLOGICAL CHARAC- TERISTICS}

To date, only a few recent studies have elucidated the role of HBV infection in the development of ICC and demonstrated that the clinicopathological features of $\mathrm{HBV}$-associated ICC were significantly different from patients without HBV infection. Zhou et al. [42] by comparing the clinicopathological characteristics of 154 HBsAg (hepatitis B surface antigen)-positive ICC patients and 163 seronegative-HBsAg ICC patients discovered that $\mathrm{HBs} A g$-positive ICC patients were found to be younger and had a higher male distribution, a higher incidence of cirrhosis and tumor encapsulation, frequent microvascular invasion, poorer tumor differentiation, a lower distribution of abnormal serum carbohydrate antigen 19-9 (CA19-9) level, and infrequent lymph node metastasis with abnormal aminotransferase levels, elevated serum alpha-fetoprotein (AFP) levels. In addition, the age and gender distribution was almost equal between HBsAg-positive ICC and HBVassociated HCC. Research of Zhou et al. [42] and Peng et al. [27] further indicated that neutrophilic infiltration was found to be more common in HBV-associated ICC patients. More recently, Tao et al. [28] found that prothrombin time was also found to be higher in HBVassociated ICC patients $(\mathrm{P}=0.030)$, complementing the studies from Zhou et al. [42] and Peng et al [27]. The above mentioned clinicopathological characteristics of $\mathrm{HBV}$-associated ICC were verified by a meta-analysis that involved 14 studies and 2842 cases [43]. HBV infection was more frequent in male patients [odds ratio $(\mathrm{OR})=$ $1.91,95 \%$ confidence interval $(\mathrm{CI})=1.06$ to 3.44$]$ and was correlated with elevated serum aspartate transaminase $(\mathrm{AST})(\mathrm{OR}=1.93,95 \% \mathrm{CI}=1.11$ to 3.35$)$ and AFP levels $(\mathrm{OR}=3.86,95 \% \mathrm{CI}=2.58$ to 5.78$)$, as well as a relatively lower level of serum CA19-9 $(\mathrm{OR}=0.47,95 \% \mathrm{CI}=0.34$ to $0.65)$ [43]. In addition, there were significant differences in the incidence of liver cirrhosis $(\mathrm{OR}=6.44,95 \% \mathrm{CI}=$ 4.33 to 9.56$)$, capsule formation $(\mathrm{OR}=6.04,95 \% \mathrm{CI}=$ 3.56 to 10.26$)$, and lymph node metastasis $(\mathrm{OR}=0.39$, $95 \% \mathrm{CI}=0.25$ to 0.58 ).

Most of relevant studies reported that lymph node metastasis was significantly reduced in $\mathrm{HBV}$-associated ICC patients compared with those without HBV infection. However, the publications could not provide any pathological evidence of this phenomenon and there was no further explanation. Gurzu et al. [45] performed immunohistochemical staining on 15 Kaposi sarcoma specimens and found that human herpesvirus 8-modified 
Table 1: A comprehensive review of survival outcomes in $\mathrm{HBV}$-associated ICC

\begin{tabular}{|c|c|c|c|c|c|c|c|c|}
\hline \multirow[t]{2}{*}{ Study } & \multirow{2}{*}{$\begin{array}{l}\text { Study } \\
\text { region }\end{array}$} & \multirow{2}{*}{$\begin{array}{l}\text { Marker } \\
\text { detection }\end{array}$} & \multirow{2}{*}{$\begin{array}{l}\text { Patients } \\
\text { (n) }\end{array}$} & \multicolumn{2}{|c|}{ Overall survival (\%) } & \multirow{2}{*}{$\begin{array}{l}\text { Median } \\
\text { survival }\end{array}$} & \multirow[t]{2}{*}{$P$ value } & \multirow[t]{2}{*}{ Outcomes } \\
\hline & & & & $1-y r$ & $5-y r$ & & & \\
\hline \multicolumn{9}{|l|}{ Zhang (2010) [50] } \\
\hline HBV-ICC & \multirow[t]{2}{*}{ China } & \multirow{2}{*}{$\begin{array}{l}\mathrm{HBsAg} / \\
\mathrm{HBcAb}\end{array}$} & 29 & 78.9 & 35.7 & $32 \mathrm{~m}$ & 0.025 & Favorable \\
\hline Non-HBV-ICC & & & 10 & 46.7 & NR & & & \\
\hline \multicolumn{9}{|l|}{ Zhou (2011) [51] } \\
\hline HBV-ICC & \multirow{4}{*}{ China } & \multirow{4}{*}{ HBsAg } & 87 & 72.4 & 41.8 & \multirow{4}{*}{ NR } & \multirow{4}{*}{0.003} & \multirow{4}{*}{ Favorable } \\
\hline \multirow[t]{3}{*}{ Non-HBV-ICC } & & & 68 & 45.6 & $(3-y r)$ & & & \\
\hline & & & & & 20.5 & & & \\
\hline & & & & & $(3-y r)$ & & & \\
\hline \multicolumn{9}{|l|}{$\mathrm{Wu}(2013)[53]$} \\
\hline HBV-ICC & \multirow[t]{2}{*}{ China } & \multirow{2}{*}{$\begin{array}{l}\mathrm{HBsAg} / \\
\mathrm{HBcAb}\end{array}$} & 97 & 42 & 15 & NR & 0.005 & Favorable \\
\hline Non-HBV-ICC & & & 41 & 24 & 0 & & & \\
\hline \multicolumn{9}{|l|}{ Liu (2013) [55] } \\
\hline HBV-ICC & \multirow[t]{2}{*}{ China } & \multirow{2}{*}{$\begin{array}{l}\mathrm{HBsAg} / \\
\mathrm{HBcAb}\end{array}$} & 37 & 45.9 & $15(3-y r)$ & $12 \mathrm{~m}$ & 0.017 & Favorable \\
\hline Non-HBV-ICC & & & 23 & 30.4 & $0(3-y r)$ & $6 \mathrm{~m}$ & & \\
\hline \multicolumn{9}{|l|}{ Luo (2014) [38] } \\
\hline HBV-ICC & \multirow[t]{2}{*}{ China } & \multirow[t]{2}{*}{$\mathrm{HBsAg}$} & 608 & NR & NR & $19 \mathrm{~m}$ & \multirow[t]{2}{*}{$<0.001$} & \multirow[t]{2}{*}{ Favorable } \\
\hline Non-HBV-ICC & & & 725 & NR & NR & $12 \mathrm{~m}$ & & \\
\hline $\begin{array}{c}\text { Wu (2015) [54] } \\
\text { HBV-ICC }\end{array}$ & China & $\begin{array}{l}\mathrm{HBsAg} / \\
\mathrm{HBcAb}\end{array}$ & 85 & 60 & 13 & $25 \mathrm{~m}$ & NA & NA \\
\hline Tao (2016) [28] & & & & & & & & \\
\hline HBV-ICC & Ching & $\mathrm{HBsAg} /$ & 20 (totol) & 27.3 & 0 & 6.9 (mean) & - & Inf \\
\hline $\mathrm{HBcAb-ICC}$ & Cimma & $\mathrm{HBcAb}$ & 39 (total) & 62.5 & 0 & 17.0 (mean) & -0.001 & Uinavorauie \\
\hline Non-HBV-ICC & & & & 87.5 & 50 & 33.0 (mean) & & \\
\hline Ahn (2016) [5] & & & & & & & & \\
\hline HBV-ICC & Korea & $\mathrm{HBsAg}$ & 37 & NR & NR & NR & NS & difference \\
\hline Non-HBV-ICC & & & 255 & & & & & \\
\hline Jeong [unpublishe & & & & & & & & \\
\hline HBV-ICC & & & 56 & 72.2 & 46.5 & $21 \mathrm{~m}$ & & \\
\hline Non-HBV-ICC & China & HBsAg & 64 & 50.0 & $(3-y r)$ & $11 \mathrm{~m}$ & 0.001 & Favorable \\
\hline & & & & & 18.0 & & & \\
\hline & & & & & $(3-y r)$ & & & \\
\hline
\end{tabular}

HBsAg: hepatitis B surface antigen, HBcAb: hepatitis B core antibody, NR: not reported, HBV-ICC: hepatitis B virusassociated intrahepatic cholangiocarcinoma, NA: not applicable, NS: not significant.

pluripotent mesenchymal cells most likely transformed into vascular endothelial cells. More recently, a publication from Nature concluded that cardiac fibroblasts could be transformed into vascular endothelial cells, thereby participating in neovascularization after cardiac injury to improve cardiac function [46]. Along with the recent discovery of the existence of activated fibroblasts (cancerassociated fibroblast, CAF) in ICC and its potential ability to promote the development of the tumor by stimulating the invasive genotype of malignant cells, CAFs (mesenchymal cells) in stromal areas of ICC may also adopt an endothelial morphology and function [47, 48]. Therefore, reduced incidence of lymph node metastasis observed in HBV-associated ICC patients could be a result of inhibited cancer-associated lymphangiogenesis via suppressing mesenchymal-to-lymphatic endothelial transition in ICC (Figure 1). However, there is no conclusive mechanism-based evidence of mesenchymal- 

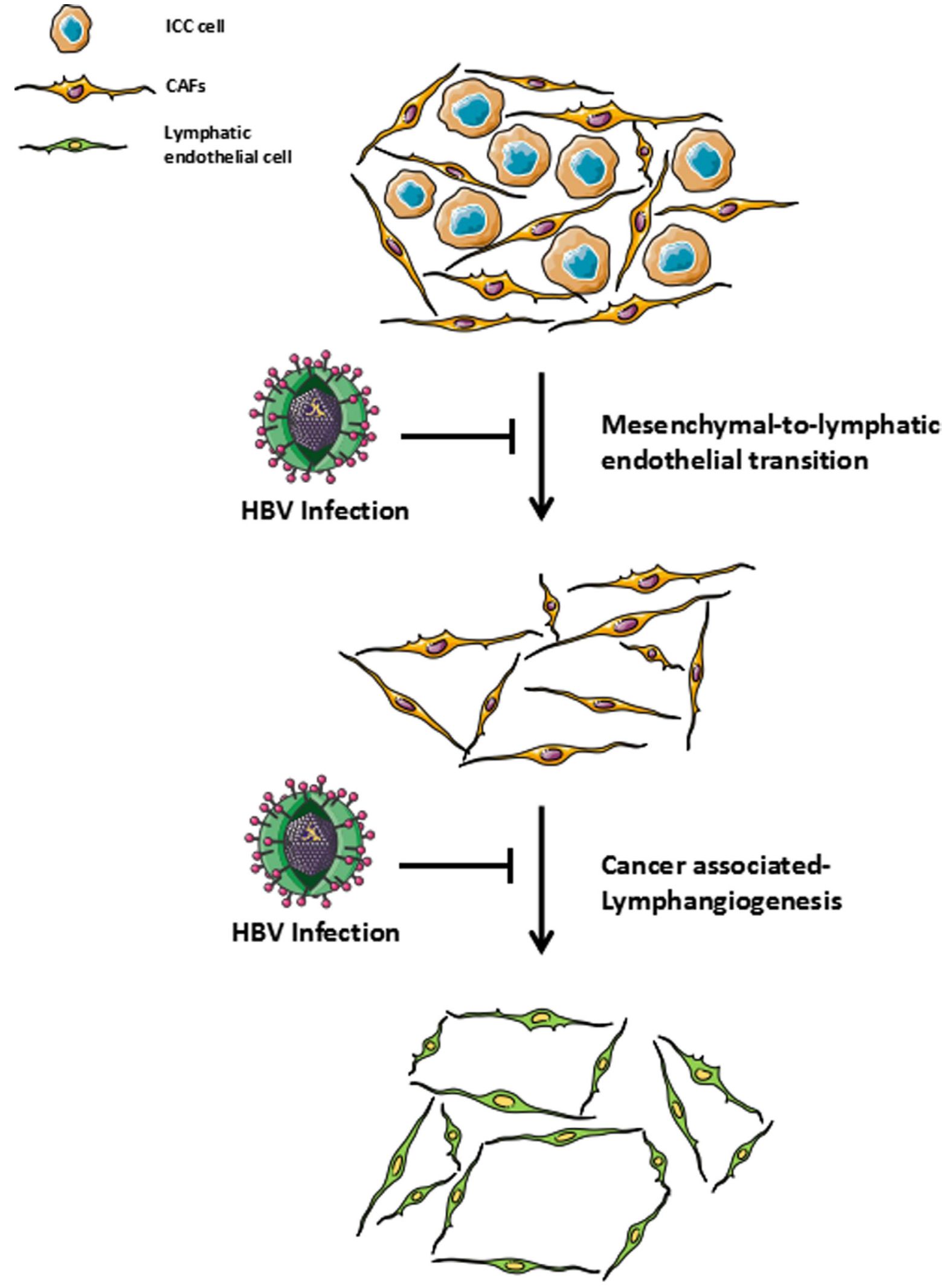

Figure 1: Role of HBV infection in cancer-associated lymphangiogenesis / HBV infection could be involved in the suppression of cancer-associated fibroblasts to adopt a lymphatic endothelial morphology and function (mesenchymalto-lymphatic endothelial transition) which has resulted in the low extent of cancer-associated lymphangiogenesis and led to a relatively low incidence of lymph node metastasis in HBV-associated ICC. 
to-lymphatic endothelial transition in ICC, which awaits our future researches.

Recently, an imaging study of 40 nodules from 32 ICC patients with cirrhosis, showed manifestations of nodules that resulted in a heterogeneous contrast enhancement pattern, of which 19 cases presented with arterial peripheral-rim enhancement, 16 cases presented with a progressive homogeneous contrast uptake within the three vascular phases, and 2 cases were not detected by CT-scan [49]. Interestingly, the nodules did not reveal any radiological features of $\mathrm{HCC}$; only ICC showed a homogeneous wash-in during the arterial and portal phases and a wash-out during the delayed venous phase, indicating that $\mathrm{HBV}$-associated ICC in cirrhotic patients display distinct vascular characteristics on CT-scan that could be applied to differentiate from HCC [49].

\section{SURVIVAL OUTCOMES}

In recent years, several publications evaluated the correlation between the presence of HBV infection and the survival outcomes of patients with ICC (Table 1). The majority of these studies insisted that HBV infection may be a favorable prognostic factor in patients with ICC $[39,40,50-56]$. However, there are still a few studies that reported $\mathrm{HBV}$ infection has no impact on the survival outcome of patients with ICC after hepatic resection [5, 31, 43, 57]. Zhang et al. [50] suggested that ICC patients with both current and past HBV infection [seropositivity of HBsAg and hepatitis B core antibody (HBcAb)] had a significantly better prognosis than patients without a history of HBV infection and deduced that the activated immune responses by current or past HBV infection may enhance anti-tumor activity against ICC. Zhou et al. [51] suggested that inhibited tumor invasiveness prolongs the survival outcome of $\mathrm{HBV}$-associated ICC patients, insisting that $\mathrm{HBV}$-associated ICC should be differentiated from HBV-negative ICC on account of different clinicopathological features and survival outcome. A mathematical model for predicting survival duration (total accuracy, 92.3\%; a positive predictive value, 93.8\%) of ICC patients after hepatectomy conducted by Jiang et al. [52] included HBV infection as a positive factor, further bolstering the objective evidence for HBV infection as a favorable prognostic factor. Wu et al. [53] also elucidated that HBV infection is a favorable prognostic factor for ICC patients due to early detection of the unexpected detection of ICC during chronic liver disease follow-up. Less than one third of HBV-associated ICC patients were found to be at stage III and IV, whereas the majority of ICC patients without HBV infection were at stage III and IV upon diagnosis. Moreover, Liu et al. [55] observed this phenomenon from a different point of view and discovered that both HBV infection and vaccination prior to surgical treatment, combined with preoperative adjuvant chemotherapy, were found to be independent prognostic factors that improved survival outcomes of patients when undergoing hepatic resection for ICC. On the contrary, Tao et al. [28] described that 1-, 3-, and 5-year cumulative survival rates of $\mathrm{HBsAg}$-positive ICC patients are significantly lower than HBV-negative ICC patients $(27.3 \%, 0 \%$, and $0 \%$ vs. $87.5 \%, 66.7 \%$, and $50.0 \%, \mathrm{P}<$ $0.001)$. More recently, Ahn et al. [5] analyzed the survival outcomes of $37 \mathrm{HBV}$-associated and $255 \mathrm{HBV}$-negative ICC patients who underwent hepatic resection, and demonstrated that their postoperative outcomes showed no significant difference, but more favorable tumor features were observed in $\mathrm{HBV}$-associated ICC patients due to a relatively earlier diagnosis.

\section{PREOPERATIVE EVALUATION AND TREATMENT}

To date, previous publications introduced curative ICC treatment heterogeneously, and all patients with ICC have been grouped into one category $[58,59]$. Previous extrapolations from clinical trials associated with the treatment of ICC has been reported, providing abundant evidence for researchers to consider a clinical practice criteria from a pragmatic perspective, but the findings are still too various and limited to establish a unified standard therapy, especially in patients with HBV-associated ICC. According to one of the major hallmarks of ICC, which is frequent metastasis, several surgeons suggested a staging laparoscopy to be performed before or during the surgical operation. A previous publication reported that $6 / 22$ ICC patients (27\%) with undetected intrahepatic or peritoneal metastasis were found to have metastasis when laparoscopy was performed [63]. However, currently there is insufficient evidence to recommend routine staging laparoscopy as an indispensable inspection for patients with HBV-associated ICC.

In recent years, prophylactic lymph node dissection has been introduced as a favorable prognostic factor for patients with ICC [66, 67]. Murakami et al. [68] documented the first 5-year survival of a periductalinfiltrating ICC patient with para-aortic nodal metastasis after a wide dissection, including regional and para-aortic nodals, in combination with a hemi-hepatectomy was performed. In addition, one of our colleagues recently found that there was no difference in the survival outcomes between patients with para-aortic nodal metastasis and patients with only regional lymph node metastasis, suggesting that micrometastases of para-aortic nodes may also be associated with the prognosis of patients with ICC [69]. To date, there is no information considering whether preventive wide nodal dissection could be a benign factor for $\mathrm{HBV}$-associated ICC. Therefore, prospective controlled investigations evaluating the efficacy of preventive lymphadenectomy in $\mathrm{HBV}$-associated ICC patients are needed.

To date, in order to allocate organs to patients 
with the optimal chance of long-term survival, it is considered impractical to perform liver transplants (LT) on hepatic cancer with a 5-year survival rate of less $50 \%$, leading to the current viewpoint that LT for ICC is unacceptable [70]. However, the guidelines from the International Liver Cancer Association recommend a thorough investigation of the standardized candidate criteria for treating ICC patients with LT in combination with neoadjuvant chemotherapy [71]. Our previous metaanalysis also revealed that neoadjuvant chemotherapy or radiotherapy followed by LT may be an alternative option in order to achieve a favorable prognosis for patients with unresectable ICC [72]. Liu et al. [55] reported that 18 of 81 patients who underwent hepatic resection in combination with adjuvant chemotherapy [transcatheter hepatic arterial chemoembolization (TACE) and systemic venous anti-neoplastic therapy] obtained a significantly prolonged 1-year and 3-year cumulative overall survival rates compared to patients who did not receive any adjuvant chemotherapy (1-year: 83.8\%, 3-year: 33.3\% vs. 1-year: $31.7 \%$, 3-year: $4.1 \% ; \mathrm{P}=0.015)$, emphasizing the indispensable role of neoadjuvant chemotherapy or radiotherapy in the treatment of ICC. As described above, HBV-associated ICC demonstrated a significantly lower tumor recurrence and more prolonged long-term survival. Therefore, it is strongly recommended that $\mathrm{HBV}$-associated ICC needs to be treated with neoadjuvant chemoradiotherapy followed by LT and adjuvant chemotherapy.

\section{ACKNOWLEDGMENTS}

This work was supported by National Natural Science Foundation of China (81300337, 81472243).

\section{CONFLICTS OF INTEREST} interest.

All the authors declare that we have no conflict of

This is a comprehensive review of the characteristics and treatments of patients with hepatitis B virusassociated intrahepatic cholangiocarcinoma. All the authors participated in the study design and reviewed the manuscript.

\section{REFERENCES}

1. Razumilava N, Gores GJ. Cholangiocarcinoma. Lancet. 2014; 383: 2168-79. doi: 10.1016/S0140-6736(13)61903-0.

2. Rizvi S, Gores GJ. Pathogenesis, diagnosis, and management of cholangiocarcinoma. Gastroenterology. 2013; 145: 1215-29. doi: 10.1053/j.gastro.2013.10.013.

3. Fujita T. An unusual risk factor for intrahepatic cholangiocarcinoma. J Hepatol. 2012; 57: 1396-7. doi: 10.1016/j.jhep.2012.07.021.
4. Palmer WC, Patel T. Are common factors involved in the pathogenesis of primary liver cancers? A meta-analysis of risk factors for intrahepatic cholangiocarcinoma. J Hepatol. 2012; 57: 69-76. doi: 10.1016/j.jhep.2012.02.022.

5. Ahn CS, Hwang S, Lee YJ, Kim KH, Moon DB, Ha TY, Song GW, Lee SG. Prognostic impact of hepatitis B virus infection in patients with intrahepatic cholangiocarcinoma. ANZ J Surg. 2016. doi: 10.1111/ans.13753.

6. Zhang $\mathrm{H}$, Yang $\mathrm{T}$, $\mathrm{Wu} \mathrm{M}$, Shen $\mathrm{F}$. Intrahepatic cholangiocarcinoma: Epidemiology, risk factors, diagnosis and surgical management. Cancer Lett. 2016; 379: 198-205. doi: 10.1016/j.canlet.2015.09.008.

7. Chaiteerakij R, Yang JD, Harmsen WS, Slettedahl SW, Mettler TA, Fredericksen ZS, Kim WR, Gores GJ, Roberts RO, Olson JE, Therneau TM, Roberts LR. Risk factors for intrahepatic cholangiocarcinoma: association between metformin use and reduced cancer risk. Hepatology. 2013; 57: 648-55. doi: 10.1002/hep.26092.

8. Lee TY, Lee SS, Jung SW, Jeon SH, Yun SC, Oh HC, Kwon S, Lee SK, Seo DW, Kim MH, Suh DJ. Hepatitis $\mathrm{B}$ virus infection and intrahepatic cholangiocarcinoma in Korea: a case-control study. Am J Gastroenterol. 2008; 103 : 1716-20. doi: 10.1111/j.1572-0241.2008.01796.x.

9. Zhou YM, Yin ZF, Yang JM, Li B, Shao WY, Xu F, Wang YL, Li DQ. Risk factors for intrahepatic cholangiocarcinoma: a case-control study in China. World J Gastroenterol. 2008; 14: 632-5. doi:

10. Matsumoto K, Onoyama T, Kawata S, Takeda Y, Harada K, Ikebuchi Y, Ueki M, Miura N, Yashima K, Koda M, Sakamoto T, Endo M, Horie Y, et al. Hepatitis B and C virus infection is a risk factor for the development of cholangiocarcinoma. Intern Med. 2014; 53: 651-4. doi:

11. Li Y, Wang H, Li D, Hu J, Wang H, Zhou D, Li Q, Jiang $\mathrm{X}$, Zhou H, Hu H. Occult hepatitis B virus infection in Chinese cryptogenic intrahepatic cholangiocarcinoma patient population. J Clin Gastroenterol. 2014; 48: 878-82. doi: 10.1097/MCG.0000000000000058.

12. Zhou YM, Cao L, Li B, Zhang XZ, Yin ZF. Expression of $\mathrm{HBx}$ protein in hepatitis $\mathrm{B}$ virus-infected intrahepatic cholangiocarcinoma. Hepatobiliary Pancreat Dis Int. 2012; 11: 532-5. doi:

13. Li M, Li J, Li P, Li H, Su T, Zhu R, Gong J. Hepatitis B virus infection increases the risk of cholangiocarcinoma: a meta-analysis and systematic review. J Gastroenterol Hepatol. 2012; 27: 1561-8. doi: 10.1111/j.14401746.2012.07207.x.

14. Shaib YH, El-Serag HB, Nooka AK, Thomas M, Brown TD, Patt YZ, Hassan MM. Risk factors for intrahepatic and extrahepatic cholangiocarcinoma: a hospital-based casecontrol study. Am J Gastroenterol. 2007; 102: 1016-21. doi: 10.1111/j.1572-0241.2007.01104.x.

15. Moeini A, Sia D, Bardeesy N, Mazzaferro V, Llovet JM. Molecular Pathogenesis and Targeted Therapies for Intrahepatic Cholangiocarcinoma. Clin Cancer Res. 2016; 
22: 291-300. doi: 10.1158/1078-0432.CCR-14-3296.

16. Saha SK, Zhu AX, Fuchs CS, Brooks GA. Forty-Year Trends in Cholangiocarcinoma Incidence in the U.S.: Intrahepatic Disease on the Rise. Oncologist. 2016; 21: 5949. doi: 10.1634/theoncologist.2015-0446.

17. Shaib YH, Davila JA, McGlynn K, El-Serag HB. Rising incidence of intrahepatic cholangiocarcinoma in the United States: a true increase? J Hepatol. 2004; 40: 472-7. doi: 10.1016/j.jhep.2003.11.030.

18. McLean L, Patel T. Racial and ethnic variations in the epidemiology of intrahepatic cholangiocarcinoma in the United States. Liver Int. 2006; 26: 1047-53. doi: 10.1111/j.1478-3231.2006.01350.x.

19. Dienstag JL. Hepatitis B virus infection. N Engl J Med. 2008; 359: 1486-500. doi: 10.1056/NEJMra0801644.

20. Liaw YF, Chu CM. Hepatitis B virus infection. Lancet. 2009; 373: 582-92. doi: 10.1016/S0140-6736(09)60207-5.

21. Lozano R, Naghavi M, Foreman K, Lim S, Shibuya K, Aboyans V, Abraham J, Adair T, Aggarwal R, Ahn SY, Alvarado M, Anderson HR, Anderson LM, et al. Global and regional mortality from 235 causes of death for 20 age groups in 1990 and 2010: a systematic analysis for the Global Burden of Disease Study 2010. Lancet. 2012; 380: 2095-128. doi: 10.1016/S0140-6736(12)61728-0.

22. Te HS, Jensen DM. Epidemiology of hepatitis B and C viruses: a global overview. Clin Liver Dis. 2010; 14: 1-21, vii. doi: 10.1016/j.cld.2009.11.009.

23. WHO. Hepatitis B. Fact Sheet. http://www.who.int/ mediacentre/factsheets/fs204/en/ (July, 2016).

24. Trepo C, Chan HL, Lok A. Hepatitis B virus infection. Lancet. 2014; 384: 2053-63. doi: 10.1016/S01406736(14)60220-8.

25. Shaib YH, El-Serag HB, Davila JA, Morgan R, McGlynn KA. Risk factors of intrahepatic cholangiocarcinoma in the United States: a case-control study. Gastroenterology. 2005; 128: 620-6. doi:

26. Zhou HB, Wang H, Zhou DX, Wang H, Wang Q, Zou SS, $\mathrm{Hu}$ HP. Etiological and clinicopathologic characteristics of intrahepatic cholangiocarcinoma in young patients. World J Gastroenterol. 2010; 16: 881-5. doi:

27. Peng NF, Li LQ, Qin X, Guo Y, Peng T, Xiao KY, Chen XG, Yang YF, Su ZX, Chen B, Su M, Qi LN. Evaluation of risk factors and clinicopathologic features for intrahepatic cholangiocarcinoma in Southern China: a possible role of hepatitis B virus. Ann Surg Oncol. 2011; 18: 1258-66. doi: 10.1245/s10434-010-1458-5.

28. Tao LY, He XD, Xiu DR. Hepatitis B virus is associated with the clinical features and survival rate of patients with intrahepatic cholangiocarcinoma. Clin Res Hepatol Gastroenterol. 2016. doi: 10.1016/j.clinre.2016.04.001.

29. Choi D, Lim JH, Lee KT, Lee JK, Choi SH, Heo JS, Jang KT, Lee NY, Kim S, Hong ST. Cholangiocarcinoma and Clonorchis sinensis infection: a case-control study in Korea. J Hepatol. 2006; 44: 1066-73. doi: 10.1016/j. jhep.2005.11.040.

30. Yamamoto S, Kubo S, Hai S, Uenishi T, Yamamoto T, Shuto T, Takemura S, Tanaka H, Yamazaki O, Hirohashi $\mathrm{K}$, Tanaka T. Hepatitis $\mathrm{C}$ virus infection as a likely etiology of intrahepatic cholangiocarcinoma. Cancer Sci. 2004; 95: 592-5. doi:

31. Wakabayashi H, Hashimoto N, Okano K, Inoue T, Kakinoki K, Izuishi K, Suzuki Y. Clinicopathological comparison between intrahepatic cholangiocarcinoma arising in livers positive and negative for hepatitis $\mathrm{B}$ or $\mathrm{C}$ virus. Liver Int. 2008; 28: 717-8. doi: 10.1111/j.1478-3231.2007.01660.x.

32. Hammill CW, Wong LL. Intrahepatic cholangiocarcinoma: a malignancy of increasing importance. J Am Coll Surg. 2008; 207: 594-603. doi: 10.1016/j. jamcollsurg.2008.04.031.

33. Yamasaki S. Intrahepatic cholangiocarcinoma: macroscopic type and stage classification. J Hepatobiliary Pancreat Surg. 2003; 10: 288-91. doi: 10.1007/s00534-002-0732-8.

34. Aishima S, Oda Y. Pathogenesis and classification of intrahepatic cholangiocarcinoma: different characters of perihilar large duct type versus peripheral small duct type. J Hepatobiliary Pancreat Sci. 2015; 22: 94-100. doi: 10.1002/ jhbp.154.

35. Kim HJ, Kim JS, Joo MK, Lee BJ, Kim JH, Yeon JE, Park JJ, Byun KS, Bak YT. Hepatolithiasis and intrahepatic cholangiocarcinoma: A review. World J Gastroenterol. 2015; 21: 13418-31. doi: 10.3748/wjg.v21.i48.13418.

36. Chen TC, Nakanuma Y, Zen Y, Chen MF, Jan YY, Yeh TS, Chiu CT, Kuo TT, Kamiya J, Oda K, Hamaguchi M, Ohno Y, Hsieh LL, et al. Intraductal papillary neoplasia of the liver associated with hepatolithiasis. Hepatology. 2001; 34: 651-8. doi: 10.1053/jhep.2001.28199.

37. Jang KT, Hong SM, Lee KT, Lee JG, Choi SH, Heo JS, Choi DW, Choi D, Lim JH. Intraductal papillary neoplasm of the bile duct associated with Clonorchis sinensis infection. Virchows Arch. 2008; 453: 589-98. doi: 10.1007/ s00428-008-0682-x.

38. Luo X, Yuan L, Wang Y, Ge R, Sun Y, Wei G. Survival outcomes and prognostic factors of surgical therapy for all potentially resectable intrahepatic cholangiocarcinoma: a large single-center cohort study. J Gastrointest Surg. 2014; 18: 562-72. doi: 10.1007/s11605-013-2447-3.

39. Li T, Qin LX, Zhou J, Sun HC, Qiu SJ, Ye QH, Wang L, Tang ZY, Fan J. Staging, prognostic factors and adjuvant therapy of intrahepatic cholangiocarcinoma after curative resection. Liver Int. 2014; 34: 953-60. doi: 10.1111/ liv.12364.

40. Yu TH, Yuan RH, Chen YL, Yang WC, Hsu HC, Jeng YM. Viral hepatitis is associated with intrahepatic cholangiocarcinoma with cholangiolar differentiation and N-cadherin expression. Mod Pathol. 2011; 24: 810-9. doi: 10.1038/modpathol.2011.41.

41. Lee CH, Chang CJ, Lin YJ, Yeh CN, Chen MF, Hsieh SY. Viral hepatitis-associated intrahepatic cholangiocarcinoma 
shares common disease processes with hepatocellular carcinoma. Br J Cancer. 2009; 100: 1765-70. doi: 10.1038/ sj.bjc. 6605063 .

42. Zhou H, Wang H, Zhou D, Wang H, Wang Q, Zou S, Tu $\mathrm{Q}, \mathrm{Wu} \mathrm{M}, \mathrm{Hu} \mathrm{H}$. Hepatitis B virus-associated intrahepatic cholangiocarcinoma and hepatocellular carcinoma may hold common disease process for carcinogenesis. Eur J Cancer. 2010; 46: 1056-61. doi: 10.1016/j.ejca.2010.02.005.

43. Wang Z, Sheng YY, Dong QZ, Qin LX. Hepatitis B virus and hepatitis $\mathrm{C}$ virus play different prognostic roles in intrahepatic cholangiocarcinoma: A meta-analysis. World J Gastroenterol. 2016; 22: 3038-51. doi: 10.3748/wjg.v22. i10.3038.

44. Wu C, Liu L, Zhao P, Tang D, Yao D, Zhu L, Wang Z. Potential Serum Markers for Monitoring the Progression of Hepatitis B Virus-Associated Chronic Hepatic Lesions to Liver Cirrhosis. Gut Liver. 2015; 9: 665-71. doi: 10.5009/ gnl14212.

45. Gurzu S, Ciortea D, Munteanu T, Kezdi-Zaharia I, Jung I. Mesenchymal-to-endothelial transition in Kaposi sarcoma: a histogenetic hypothesis based on a case series and literature review. PLoS One. 2013; 8: e71530. doi: 10.1371/journal. pone.0071530.

46. Ubil E, Duan J, Pillai IC, Rosa-Garrido M, Wu Y, Bargiacchi F, Lu Y, Stanbouly S, Huang J, Rojas M, Vondriska TM, Stefani E, Deb A. Mesenchymal-endothelial transition contributes to cardiac neovascularization. Nature. 2014; 514: 585-90. doi: 10.1038/nature13839.

47. Shiga K, Hara M, Nagasaki T, Sato T, Takahashi H, Takeyama H. Cancer-Associated Fibroblasts: Their Characteristics and Their Roles in Tumor Growth. Cancers (Basel). 2015; 7: 2443-58. doi: 10.3390/cancers7040902.

48. Sirica AE. The role of cancer-associated myofibroblasts in intrahepatic cholangiocarcinoma. Nat Rev Gastroenterol Hepatol. 2011; 9: 44-54. doi: 10.1038/nrgastro.2011.222.

49. Iavarone M, Piscaglia F, Vavassori S, Galassi M, Sangiovanni A, Venerandi L, Forzenigo LV, Golfieri R, Bolondi L, Colombo M. Contrast enhanced CT-scan to diagnose intrahepatic cholangiocarcinoma in patients with cirrhosis. J Hepatol. 2013; 58: 1188-93. doi: 10.1016/j. jhep.2013.02.013.

50. Zhang L, Cai JQ, Zhao JJ, Bi XY, Tan XG, Yan T, Li C, Zhao P. Impact of hepatitis B virus infection on outcome following resection for intrahepatic cholangiocarcinoma. J Surg Oncol. 2010; 101: 233-8. doi: 10.1002/jso.21488.

51. Zhou HB, Wang H, Li YQ, Li SX, Wang H, Zhou DX, Tu QQ, Wang Q, Zou SS, Wu MC, Hu HP. Hepatitis B virus infection: a favorable prognostic factor for intrahepatic cholangiocarcinoma after resection. World J Gastroenterol. 2011; 17: 1292-303. doi: 10.3748/wjg.v17.i10.1292.

52. Jiang BG, Ge RL, Sun LL, Zong M, Wei GT, Zhang YJ. Clinical parameters predicting survival duration after hepatectomy for intrahepatic cholangiocarcinoma. Can J Gastroenterol. 2011; 25: 603-8. doi:
53. Wu ZF, Yang N, Li DY, Zhang HB, Yang GS. Characteristics of intrahepatic cholangiocarcinoma in patients with hepatitis B virus infection: clinicopathologic study of resected tumours. J Viral Hepat. 2013; 20: 306-10. doi: 10.1111/jvh.12005.

54. Wu ZF, Wu XY, Zhu N, Xu Z, Li WS, Zhang HB, Yang N, Yao XQ, Liu FK, Yang GS. Prognosis after resection for hepatitis $\mathrm{B}$ virus-associated intrahepatic cholangiocarcinoma. World J Gastroenterol. 2015; 21: 935 43. doi: 10.3748/wjg.v21.i3.935.

55. Liu RQ, Shen SJ, Hu XF, Liu J, Chen LJ, Li XY. Prognosis of the intrahepatic cholangiocarcinoma after resection: hepatitis B virus infection and adjuvant chemotherapy are favorable prognosis factors. Cancer Cell Int. 2013; 13: 99. doi: 10.1186/1475-2867-13-99.

56. Zhang GW, Lin JH, Qian JP, Zhou J. Identification of risk and prognostic factors for patients with clonorchiasisassociated intrahepatic cholangiocarcinoma. Ann Surg Oncol. 2014; 21: 3628-37. doi: 10.1245/s10434-0143710-x.

57. Asayama Y, Aishima S, Taguchi K, Sugimachi K, Matsuura S, Masuda K, Tsuneyoshi M. Coexpression of neural cell adhesion molecules and bcl-2 in intrahepatic cholangiocarcinoma originated from viral hepatitis: relationship to atypical reactive bile ductule. Pathol Int. 2002; 52: 300-6. doi:

58. Lubezky N, Facciuto M, Harimoto N, Schwartz ME, Florman SS. Surgical treatment of intrahepatic cholangiocarcinoma in the USA. J Hepatobiliary Pancreat Sci. 2015; 22: 124-30. doi: 10.1002/jhbp.157.

59. Tan JC, Coburn NG, Baxter NN, Kiss A, Law CH. Surgical management of intrahepatic cholangiocarcinoma-a population-based study. Ann Surg Oncol. 2008; 15: 600-8. doi: 10.1245/s10434-007-9627-x.

60. Ali SM, Clark CJ, Mounajjed T, Wu TT, Harmsen WS, Reid-Lombardo KM, Truty MJ, Kendrick ML, Farnell MB, Nagorney DM, Que FG. Model to predict survival after surgical resection of intrahepatic cholangiocarcinoma: the Mayo Clinic experience. HPB (Oxford). 2015; 17: 244-50. doi: 10.1111/hpb.12333.

61. Chung YE, Kim MJ, Park YN, Choi JY, Pyo JY, Kim YC, Cho HJ, Kim KA, Choi SY. Varying appearances of cholangiocarcinoma: radiologic-pathologic correlation. Radiographics. 2009; 29: 683-700. doi: 10.1148/ rg.293085729.

62. Bruix J, Sherman M, Practice Guidelines Committee AAftSoLD. Management of hepatocellular carcinoma. Hepatology. 2005; 42: 1208-36. doi: 10.1002/hep.20933.

63. Weber SM, Jarnagin WR, Klimstra D, DeMatteo RP, Fong Y, Blumgart LH. Intrahepatic cholangiocarcinoma: resectability, recurrence pattern, and outcomes. J Am Coll Surg. 2001; 193: 384-91. doi:

64. Mavros MN, Economopoulos KP, Alexiou VG, Pawlik TM. Treatment and Prognosis for Patients With Intrahepatic 
Cholangiocarcinoma: Systematic Review and Metaanalysis. JAMA Surg. 2014; 149: 565-74. doi: 10.1001/ jamasurg.2013.5137.

65. de Jong MC, Nathan H, Sotiropoulos GC, Paul A, Alexandrescu S, Marques H, Pulitano C, Barroso E, Clary BM, Aldrighetti L, Ferrone CR, Zhu AX, Bauer TW, et al. Intrahepatic cholangiocarcinoma: an international multiinstitutional analysis of prognostic factors and lymph node assessment. J Clin Oncol. 2011; 29: 3140-5. doi: 10.1200/ JCO.2011.35.6519.

66. Choi SB, Kim KS, Choi JY, Park SW, Choi JS, Lee WJ, Chung JB. The prognosis and survival outcome of intrahepatic cholangiocarcinoma following surgical resection: association of lymph node metastasis and lymph node dissection with survival. Ann Surg Oncol. 2009; 16: 3048-56. doi: 10.1245/s10434-009-0631-1.

67. Adachi T, Eguchi S. Lymph node dissection for intrahepatic cholangiocarcinoma: a critical review of the literature to date. J Hepatobiliary Pancreat Sci. 2014; 21: 162-8. doi: 10.1002/jhbp.30.

68. Murakami Y, Yokoyama T, Takesue Y, Hiyama E, Yokoyama Y, Kanehiro T, Uemura K, Matsuura Y. Longterm survival of peripheral intrahepatic cholangiocarcinoma with metastasis to the para-aortic lymph nodes. Surgery. 2000; 127: 105-6. doi: 10.1067/msy.2000.99057.
69. Gu J, Xia L, Xu B, Lu T, Halmurat O, Wang J, Zhang J, Ding Y, Xia Q. Clinical prognostic significance of regional and extended lymphadenectomy for biliary cancer with para-aortic lymph node metastasis: A systematic review and meta-analysis. Dig Liver Dis. 2016; 48: 717-25. doi: 10.1016/j.dld.2016.03.019.

70. Starzl TE, Fung JJ. Themes of liver transplantation. Hepatology. 2010; 51: 1869-84. doi: 10.1002/hep.23595.

71. Bridgewater J, Galle PR, Khan SA, Llovet JM, Park JW, Patel T, Pawlik TM, Gores GJ. Guidelines for the diagnosis and management of intrahepatic cholangiocarcinoma. J Hepatol. 2014; 60: 1268-89. doi: 10.1016/j. jhep.2014.01.021.

72. Gu J, Bai J, Shi X, Zhou J, Qiu Y, Wu Y, Jiang C, Sun $\mathrm{X}, \mathrm{Xu} \mathrm{F}$, Zhang Y, Ding Y. Efficacy and safety of liver transplantation in patients with cholangiocarcinoma: a systematic review and meta-analysis. Int J Cancer. 2012; 130: 2155-63. doi: 10.1002/ijc.26019. 